\title{
PENGEMBANGAN BISKUIT MOCAF-GARUT DENGAN SUBSTITUSI HATI SEBAGAI ALTERNATIF BISKUIT TINGGI ZAT BESI UNTUK BALITA
}

\author{
(Development of biscuit mocaf-arrowroot substituted liver as alternative biscuit with high iron for \\ children under five years)
}

\author{
Friska Citra Agustia ${ }^{1 *}$, Yovita Puri Subardjo ${ }^{1}$, Hesti Permata Sari ${ }^{1}$ \\ 'Program Studi Ilmu Gizi, Fakultas Ilmu-ilmu Kesehatan, Universitas Jenderal Soedirman, \\ Purwokerto 53123
}

\begin{abstract}
The aim of this study was to determine the best formula and character of biscuit made by mocaf-arrowroot substituted with liver (chicken and cow), we conducted a factorial randomized design experiment. Proportion of mocaf-arrowroot-liver substitution were 75:10:15; 70:10:20 and 65:10:25; and type of material substitution were chicken's liver and cow's liver. Analyzed variables were 1) chemical properties (water content, total fat, total protein, carbohydrate by difference, ash content, iron content and energy) and 2) sensory properties. Hedonic test were conducted to determine the level of consumer acceptance of 15 semi-trained panelists. Data were analyzed by F-test and Duncan's Multiple Range Test (DMRT). The best treatment was from mocaf $75 \%$ : arrowroot $10 \%$ and chicken's liver $15 \%$ with water content $5.93 \%$ wet basis (bb), ash content $1.89 \%$ dry basis (bk), protein content $5.83 \%$ bk, fat content $13.55 \%$ bk, carbohydrate by difference $78.71 \%$ bk and iron content $14.05 \mathrm{mg} / 100 \mathrm{~g}$. 1 serving of biscuit $(22,8)$ can reach the intake of iron for $3.3 \mathrm{mg}$ as $35.5-40 \%$ daily iron needs of children under five years.
\end{abstract}

Keywords: arrowroot, biscuit, chicken's liver, cow's liver, mocaf

\begin{abstract}
ABSTRAK
Penelitian ini bertujuan untuk mengolah alternatif makanan baru berupa biskuit berbahan dasar mocaf garut yang disubstitusi bahan tinggi protein dan zat besi yaitu hati ayam dan hati sapi. Rancangan penelitian menggunakan Rancangan Acak Kelompok. Faktor perlakuan terdiri atas proporsi mocafgarut: bahan substitusi (P), 75:10:15 (P1); 70:10:20 (P2); dan 65:10:25 (P3) dan jenis bahan substitusi (J) yaitu hati ayam (J1) dan hati sapi (J2). Untuk meningkatkan zat besi ke dalam produk ditambahkan bayam merah yaitu 5\%. Variabel yang dikaji adalah sifat kimia (kadar air, abu, lemak total, protein total, karbohidrat by difference, kadar zat besi, dan nilai energi) dan sifat organoleptik (warna, tekstur, aroma, flavor, dan kesukaan) diujikan kepada 15 panelis semi terlatih. Data dianalisis dengan Uji F (anova) dan dilanjutkan dengan DMRT (Duncan Multiple Range Test). Perlakuan terbaik berdasarkan uji indeks efektivitas adalah biskuit P1J1 (proporsi mocaf-garut: bahan substitusi 75:10:15 dan jenis bahan substitusi hati ayam), memiliki kandungan energi 432,95 kkal/100 g dengan nilai rata-rata kadar air 5,93\% basis basah (bb), kadar abu 1,89\% basis kering (bk), kadar protein total 5,83\%bk, kadar lemak total $13,55 \%$ bk, kadar karbohidrat $78,71 \%$ bk dan kadar zat besi $14,05 \mathrm{mg} / 100 \mathrm{~g}$. Satu takaran saji biskuit $(22,8 \mathrm{~g})$ dapat memenuhi asupan zat besi sebesar 3,2 mg atau setara dengan 35,5-40\% kebutuhan akan zat besi harian balita.
\end{abstract}

Kata kunci: biskuit, garut, hati ayam, hati sapi, mocaf

\section{PENDAHULUAN}

Ready to Use Supplementary Food (RUSF) merupakan metode intervensi gizi dengan pemberian alternatif makanan yang akhir-akhir ini sedang digalakkan untuk mengatasi masalah defisiensi zat gizi terutama anemia (Davis 2014).
RUSF merupakan makanan siap santap yang dibuat sebagai tambahan makanan padat energi dan kaya zat gizi. Biskuit adalah salah satu bentuk RUSF yang digemari semua usia terutama balita. Menurut Standar Nasional Indonesia (SNI) 29732011, biskuit adalah produk bakery kering yang dibuat dengan cara memanggang adonan yang

\footnotetext{
"Korespondensi: Telp:+6281621122, Surel: furissuka@yahoo.co.id
} 
terbuat dari tepung terigu dengan atau tanpa substitusinya, minyak atau lemak, dengan atau tanpa penambahan bahan pangan lain dan bahan tambahan pangan yang diizinkan. Penelitian produk biskuit untuk balita telah banyak dilakukan salah satunya oleh Mervina et al. (2012) tentang pembuatan biskuit dengan substitusi tepung lele dumbo dan isolat protein kedelai untuk balita gizi kurang, sedangkan Limson (2011) menyatakan biskuit yang difortifikasi zat besi memiliki bioavailabilitas besi dan karaktersitik organoleptik yang baik sehingga menjadi alternatif makanan yang menjanjikan untuk mengurangi defisiensi besi pada balita.

Selama ini kebutuhan terigu di Indonesia diperoleh dengan cara mengimpor dalam jumlah besar, sehingga dibutuhkan alternatif bahan pangan lain yang dapat digunakan sebagai pensubstitusi atau bahkan pengganti tepung terigu (Widaningrum et al. 2005). Indonesia memiliki aneka sumber daya lokal yang bisa menggantikan gandum, seperti sagu, ubi kayu dan garut. Agustia et al. (2016) telah meneliti pembuatan mi bebas gluten tinggi protein dari pati sagu sebagai salah satu usaha diversifikasi pangan. Selain itu Sianturi dan Marliyati (2014) juga telah meneliti pembuatan flakes dari tepung komposit pati garut dan tepung singkong.

Modified Cassava Flour (Mocaf) adalah salah satu tepung hasil olahan ubi kayu yang difermentasi. Kandungan pati mocaf yang tinggi dapat digunakan untuk substitusi tepung terigu dalam pembuatan biskuit (Subagjo et al. 2008). Kualitas biskuit mocaf dapat ditingkatkan dengan penambahan bahan berpati misalnya pati garut, dimana pati garut memiliki daya kembang yang tinggi, yaitu $54 \%$ dan nilai cerna pati $84,35 \%$ sehingga menghasilkan biskuit yang lebih lembut, renyah dan mudah dicerna (Aini \& Wirawani 2013).

Guna meningkatkan kandungan zat besi pada biskuit mocaf-garut maka ditambahkan bahan pangan sumber zat besi seperti hati ayam dan hati sapi serta bayam merah. Menurut Escott-Stump (2005), zat besi yang bersumber dari protein hewani berbentuk $\mathrm{Fe}^{3+}$ sehingga mudah diserap dan digunakan oleh tubuh. Hati ayam buras mengandung zat besi $24,94 \mathrm{mg} / 100 \mathrm{~g}$ (Simbolon et al. 2012). Hati ayam mengandung protein hewani yang memiliki mutu protein tinggi yaitu sebesar 16,92 g/100 g, pada hati sapi terkandung zat besi $6,6 \mathrm{mg} / 100 \mathrm{~g}$ dan protein $19,7 \mathrm{~g} / 100 \mathrm{~g}$ sedangkan bayam merah mengandung zat besi $7 \mathrm{mg} / 100 \mathrm{~g}$ dan vitamin C $62 \mathrm{mg} / 100 \mathrm{~g}$ (USDA 2014). Kandungan protein yang tinggi pada hati
$( \pm 15 \mathrm{~g} / 100 \mathrm{~g})$ berperan dalam meningkatkan absorbsi zat besi nonheme, pembentuk sel darah merah dan untuk mempertahankan tekanan osmosis darah (Huma et al. 2007). Bayam merah juga mengandung vitamin $\mathrm{C}$ cukup tinggi sehingga sesuai untuk ditambahkan pada biskuit yang mengandung zat besi tinggi. Vitamin $\mathrm{C}$ akan membantu penyerapan zat besi dalam tubuh.

Adanya substitusi hati ayam dan hati sapi serta penambahan bayam merah pada pembuatan biskuit mocaf-garut akan berkontribusi terutama pada kandungan zat besi produk, dan juga akan memengaruhi karakteristik organoleptik produk. Oleh karena itu, diperlukan kajian untuk menentukan proporsi mocaf-garut-bahan substitusi dan jenis bahan substitusi (hati) yang tepat agar diperoleh produk biskuit dengan kandungan zat besi yang tinggi dan karakteristik organoleptik yang dapat diterima.

\section{METODE}

\section{Desain, tempat dan waktu}

Penelitian ini menggunakan Rancangan Acak Faktorial. Faktor perlakuan terdiri atas; proporsi mocaf : garut : bahan substitusi $(\mathrm{P} ; \mathrm{b} / \mathrm{b})$ $\mathrm{P} 1=75: 10: 15 ; \quad \mathrm{P} 2=70: 10: 20$ dan $\mathrm{P} 3=65: 10: 25$ dan jenis bahan substitusi (J) J1=hati ayam dan $\mathrm{J} 2=$ hati sapi. Dari kedua faktor diperoleh perlakuan sebanyak $3 \times 2=6$ perlakuan yaitu $P 1 J 1$, P1J2, P2J1, P2J2, P3J1, dan P3J2. Tiap perlakuan diulang 3 kali sehingga diperoleh 18 kombinasi perlakuan. Penelitian dilaksanakan selama 8 bulan pada bulan Maret hingga Oktober 2016, berlokasi di Laboratorium Gizi Kuliner Prodi Ilmu Gizi Fikes dan Laboratorium Teknologi Pengolahan, Jurusan Teknologi Pertanian, Fakultas Pertanian, UNSOED.

\section{Bahan dan alat}

Bahan utama adalah mocaf dan garut yang diperoleh dari KWT Annisa Badamita Banjarnegara, sedangkan hati ayam, hati sapi, bayam merah, gula pasir, garam, mentega dan telur diperoleh dari Pasar Wage Purwokerto. Bahan kimia yang diperlukan dalam penelitian ini yaitu 1) pereaksi untuk analisis kadar lemak metode ekstraksi langsung Soxhlet AOAC 1995 meliputi pelarut hexana; 2) pereaksi untuk analisis kadar protein dengan menggunakan metode Mikro Kjeldahl, meliputi $\mathrm{NaOH} 30 \%, \mathrm{H}_{3} \mathrm{BO}_{3}, \mathrm{H}_{2} \mathrm{SO}_{4}$, indikator metal merah-metilen biru, aquades.

Alat utama yang digunakan pada pembuatan produk adalah alat masak skala rumah tangga, blender dan ayakan stainless steel 60 mesh, se- 
dangkan alat yang digunakan dalam analisis kandungan gizi adalah neraca analitik, oven elektrik, pipet mikro, cawan porselen, tanur, desikator, labu takar, penjepit, soxhlet, labu kjeldahl, alat destilasi, labu Erlenmeyer, gelas ukur, vortex, buret, pipet, kertas saring sentrifugasi, dan spektrofotometer.

\section{Tahapan penelitian}

Pengolahan biskuit mocaf-garut dengan substitusi hati. Penelitian ini diawali dengan melakukan formulasi biskuit mocaf-garut, setelah itu formula yang dihasilkan diuji dan dianalisis sifat organoleptiknya untuk mendapatkan biskuit terbaik. Penentuan proporsi antara mocaf:garut:bahan substitusi didasarkan pada penelitian pendahuluan (trial-error) yang sudah dilakukan. Tujuannya untuk menentukan batas maksimal bahan substitusi (hati) pada produk biskuit sehingga dihasilkan biskuit tinggi zat besi dengan karakteristik sensori yang masih disukai. Penetapan proporsi bahan substitusi (hati) pada penelitian ini yaitu 15, 20 dan 25\%. Penambahan bahan substitusi (hati) lebih dari 25\% menghasilkan biskuit yang berbau sangat amis dan tidak disukai, sehingga ditetapkan batas tertinggi penambahan bahan substitusi adalah $25 \%$. Penambahan bayam merah juga ditetapkan berdasarkan trial-error. Penambahan bayam merah ini bertujuan untuk meningkatkan kandungan zat besi namun tidak sebagai faktor perlakuan. Berdasarkan trial-error penambahan bayam merah sebanyak $10 \%$ tidak berbeda hasilnya dengan penambahan sebanyak $5 \%$, dan penambahan bayam merah lebih dari $15 \%$ membuat warna dan aroma biskuit kurang disukai, sehingga ditetapkan penambahan bayam merah sebanyak $5 \%$.

Pengolahan biskuit mocaf-garut diawali dengan pencampuran (pengocokan dengan mixer) gula dan mentega sebanyak masing-masing $20 \%$, kemudian telur sebanyak $20 \%$, baking powder $1 \%$ dan garam 3\% dicampurkan sampai merata membentuk adonan. Bahan substitusi hati ayam dan hati sapi disiapkan dengan cara dicincang halus kemudian disaring dalam saringan kawat dan di steam blanching selama 5 menit, proses ini bertujuan untuk menghilangkan atau menurunkan cemaran kimia maupun mikrobiologi yang kemungkinan terdapat pada hati. Hati ayam dan hati sapi ditambahkan ke dalam adonan biskuit dalam persentase sesuai perlakuan. Selain itu, ke dalam adonan juga ditambahkan bayam merah sebanyak $5 \%$ yang sebelumnya telah di steam blanching selama 5 menit dan diblender. Adonan dikocok menggunakan mixer selama \pm 5 menit supaya bahan substitusi hati dan bayam merata. Kemudian ke dalam adonan ditambahkan mocaf, garut (sesuai persentase perlakuan) dan susu skim (5\%) yang telah diayak sebelumnya, lalu diuleni sampai bisa dilakukan pencetakan. Perlakuan selanjutnya ialah pengovenan pada suhu $150^{\circ} \mathrm{C}$ selama \pm 40 menit.

Penentuan jumlah biskuit yang direkomendasikan untuk dikonsumsi. Langkah awal untuk menentukan jumlah biskuit yang direkomendasikan yaitu dengan membandingkan komposisi gizi biskuit hasil perlakuan terbaik dengan syarat PMT biskuit yang direkomendasikan oleh Kemenkes (2009). Biskuit terbaik yaitu perlakuan P1J1 (proporsi mocaf : garut : bahan substitusi= 75:10:15, dengan bahan substitusi hati ayam) dalam $100 \mathrm{~g}$ biskuit mengandung energi sebesar 432,95 kkal (minimal $400 \mathrm{kkal}$ ); protein sebesar 5,83 g (minimal 5,3 g); lemak sebesar 13,55 g (minimal 12); karbohidrat sebesar 78,71 g dan zat besi 14,05 $\mathrm{mg}$ (minimal 9,1 $\mathrm{g}$ atau persaji zat besi PMT biskuit per $35 \mathrm{~g}$ minimal 3,2 $\mathrm{mg}$ ).

Berdasarkan penelitian ini, diketahui bahwa berat satu keping biskuit adalah 4 g. Dengan demikian, untuk menentukan takaran saji biskuit mocaf-garut terbaik dapat dilakukan perhitungan sebagai berikut: diketahui kandungan zat besi biskuit terbaik (P1J1) per $100 \mathrm{~g}=14,05 \mathrm{mg}$, kandungan zat besi biskuit terbaik (P1J1) per $35 \mathrm{~g}$ $=4,91 \mathrm{mg}$, kandungan zat besi PMT biskuit per $35 \mathrm{~g}=3,2 \mathrm{mg}$, berat satu keping biskuit=4 $\mathrm{g}$.

Dicari: $X=$ Jumlah $g$ biskuit yang dibutuhkan untuk menghasilkan $\mathrm{mg}$ zat besi yang sama dengan syarat PMT biskuit dan $\mathrm{Y}=$ Jumlah keping biskuit yang dibutuhkan per hari.

$$
\begin{aligned}
& \text { Kandungan zat besi biskuit terpilih (P1 J1) per } 35 \mathrm{~g}=\frac{35}{\mathrm{X}} \\
& \text { Kandungan zat besi PMT biskuit per } 35 \mathrm{~g} \\
& \begin{array}{l}
\frac{4,91}{3,2}=\frac{35}{\mathrm{X}} \\
\mathrm{X}=22,8 \mathrm{~g} \\
Y=\frac{\mathrm{X}}{\text { berat satu keping biskuit }} \\
=\frac{22,8 \mathrm{~g}}{4 \mathrm{~g}}=5,7 \text { atau } 6 \text { keping biskuit }
\end{array}
\end{aligned}
$$

Berdasarkan perhitungan, Jumlah keping biskuit yang dikonsumsi dalam 1 takaran saji sejumlah 6 keping biskuit.

\section{Pengolahan dan analisis data}

Uji organoleptik (Soekarto 1985) dilakukan untuk mengetahui tingkat penerimaan konsumen terhadap warna, tekstur, aroma, rasa dan kesukaan biskuit mocaf-garut substitusi hati. 
Pengujian terhadap biskuit dilakukan oleh panelis semi terlatih sebanyak 15 orang dengan metode uji skoring. Uji ini biasanya memberikan nilai secara kuantitatif dengan skoring (angka) yang sudah disepakati sebelumnya yaitu dengan rentang 1 (terendah) sampai 4 (tertinggi). Menurut Soekarto (1985), cara melatih panelis semi terlatih yaitu panelis diseleksi dengan cara wawancara tentang kebiasaan konsumsi, khususnya konsumsi biskuit dan pengalaman menjadi panelis uji kesukaan biskuit. Panelis yang terpilih selanjutnya diberikan penjelasan dan pengenalan dari beberapa kriteria atribut yang akan diuji. Kriteria inklusi panelis adalah laki-laki dan perempuan berusia 18-22 tahun, sehat dan telah mengikuti mata kuliah uji sensori.

Biskuit mocaf-garut substitusi hati juga dianalisis mutu gizinya meliputi kadar air (metode oven kering), kadar abu (metode kering), protein (metode mikro-kjedahl), lemak (metode soxhlet), karbohidrat by difference dan zat besi menggunakan metode spektrofotometer Apriyantono et al. (1989). Data dianalisis menggunakan analysis of variance atau analisis ragam pada taraf 95\% dan apabila ada pengaruh nyata $(\mathrm{p}<0,05)$ dilanjutkan dengan Duncan's Multiple Range Test (DMRT) pada taraf 5\%. Data diolah menggunakan Microsoft Excel 2010 dan SPSS 16.0 for Windows. Cara untuk menentukan biskuit terbaik yaitu menggunakan metode indeks efektifitas.

\section{HASIL DAN PEMBAHASAN}

\section{Hati ayam, hati sapi, dan bayam merah}

Tabel 1 menunjukkan kadar protein dan zat besi hati ayam dan hati sapi serta bayam merah cukup tinggi. Menurut Onabolu et al. (2001) dan Subagjo et al. (2008) mocaf memiliki kadar protein yang rendah yaitu $1 \%$ bk, sedangkan menurut Faridah et al. (2014), kadar protein pati garut lebih rendah yaitu $0,24 \%$ bk dan syarat standar mutu nasional biskuit untuk kadar protein minimal adalah 5\% (SNI 2973:2011). Oleh karena itu, hati ayam dan hati sapi sesuai digunakan sebagai bahan substitusi pada pembuatan biskuit mocafgarut terutama untuk meningkatkan kadar protein dan kadar zat besinya. Santosa et al. (2016) menyatakan bubur bayi instan dari ubi jalar ungu yang diberi tambahan hati ayam sebagai fortifikan besi memiliki kadar zat besi lebih tinggi dari pada bubur bayi instan tanpa fortifikan.

\section{Formulasi biskuit mocaf-garut substitusi hati}

Penetapan formula biskuit mocaf-garut dengan berbagai persentase substitusi dilakukan dengan trial-error. Faktor perlakuan yang digunakan pada rancangan formula adalah proporsi antara mocaf - garut - bahan substitusi (P) dan jenis bahan substitusi (J). Biskuit mocaf-garut yang diharapkan dapat menjadi biskuit alternatif makanan selingan tinggi zat besi dan dapat berkontribusi mencukupi kebutuhan balita akan zat besi harian. Pembuatan biskuit dilakukan dengan mensubstitusi hati ayam atau hati sapi. Tabel 2 menunjukkan formula biskuit mocaf-garut substitusi hati.

\section{Sifat kimia biskuit mocaf-garut substitusi hati} Hasil analisis ragam (Uji F) dan DMRT $5 \%$ sifat kimia biskuit mocaf-garut dapat dilihat pada Tabel 3. Hasil uji statistik menunjukkan bahwa secara umum perlakuan proporsi mocaf:garut:bahan substitusi $(\mathrm{P})$ hanya berpengaruh terhadap kadar protein dan karbohidrat biskuit, sedangkan perlakuan jenis bahan substitusi $(\mathrm{J})$ berpengaruh terhadap semua variabel kimia dan tidak berpengaruh terhadap kadar abu. Interaksi perlakuan proporsi dan jenis dari bahan substitusi (PxJ) hanya berpengaruh terhadap kadar air, lemak, dan energi biskuit.

\section{Kadar air}

Tabel 3 menunjukkan kadar air biskuit mocaf-garut dengan substitusi hati berkisar antara 4-5\%. Hal ini sesuai dengan penelitian Ashaye et al. (2015), biskuit yang terbuat dari ubi kayu $100 \%$ dan dengan disubstitusi kacang gude 10$30 \%$ memiliki kadar air berkisar 3-5\%. Nilai kadar air yang dihasilkan dari produk biskuit dalam penelitian ini sudah sesuai dari standar kadar air yang telah ditetapkan oleh SNI 2973:2011, yaitu maksimum 5\%.

Tabel 1. Hasil analisis sifat kimia hati ayam, hati sapi dan bayam merah

\begin{tabular}{lcccccc}
\hline Jenis Bahan & $\begin{array}{c}\text { Kadar air } \\
(\% \mathrm{bb})\end{array}$ & $\begin{array}{c}\text { Kadar abu } \\
(\% \mathrm{bk})\end{array}$ & $\begin{array}{c}\text { Kadar zat } \\
\text { besi }(\mathrm{mg})\end{array}$ & $\begin{array}{c}\text { Kadar protein } \\
(\% \mathrm{bk})\end{array}$ & $\begin{array}{c}\text { Kadar karbohidrat } \\
(\% \mathrm{bk})\end{array}$ & $\begin{array}{c}\text { Kadar lemak } \\
(\% \mathrm{bk})\end{array}$ \\
\hline Hati sapi & 67,27 & 1,77 & 9,95 & 19,70 & 3,39 & 7,89 \\
Hati ayam & 75,68 & 1,70 & 17,38 & 15,59 & 1,63 & 1,63 \\
Bayam merah & 90,53 & 1,53 & 14,08 & 3,31 & 4,17 & 0,47 \\
\hline
\end{tabular}


Tabel 2. Formula biskuit mocaf-garut substitusi hati

\begin{tabular}{lcccccc}
\hline \multicolumn{1}{c}{ Bahan (\%) } & P1J1 & P1J2 & P2J1 & P2J2 & P3J1 & P3J2 \\
\hline Mentega & 20 & 20 & 20 & 20 & 20 & 20 \\
Gula & 20 & 20 & 20 & 20 & 20 & 20 \\
Garam & 1 & 1 & 1 & 1 & 1 & 1 \\
Susu Skim & 5 & 5 & 5 & 5 & 5 & 5 \\
Baking powder & 1 & 1 & 1 & 1 & 1 & 1 \\
Telur & 20 & 20 & 20 & 20 & 20 & 20 \\
Bayam merah & 5 & 5 & 5 & 5 & 5 & 5 \\
Mocaf-garut & $75: 10$ & $75: 10$ & $70: 10$ & $70: 10$ & $65: 10$ & $65: 10$ \\
Hati ayam & 15 & 0 & 20 & 0 & 25 & 0 \\
Hati sapi & 0 & 15 & 0 & 20 & 0 & 25 \\
Total adonan (g) & 172 & 172 & 172 & 172 & 172 & 172 \\
\hline
\end{tabular}

Tabel 3. Hasil analisis ragam (Uji F) dan DMRT 5\% sifat kimia biskuit mocaf-garut substitusi hati

\begin{tabular}{|c|c|c|c|c|c|c|c|}
\hline Data & $\begin{array}{c}\text { Air } \\
(\% \mathrm{bb})\end{array}$ & $\begin{array}{c}\text { Abu } \\
(\% \mathrm{bk})\end{array}$ & $\begin{array}{c}\text { Lemak } \\
(\% \mathrm{bk})\end{array}$ & $\begin{array}{c}\text { Protein } \\
(\% \text { bk })\end{array}$ & $\begin{array}{c}\text { Karbohidrat } \\
(\% \text { bk) }\end{array}$ & $\begin{array}{l}\text { Besi } \\
(\mathrm{mg})\end{array}$ & $\begin{array}{l}\text { Energi } \\
(\mathrm{kkal})\end{array}$ \\
\hline \multicolumn{8}{|c|}{ Pengaruh Proporsi $(\mathrm{P})$} \\
\hline P1 & 4,61 & 1,80 & 15,91 & $6,08^{\mathrm{c}}$ & $76,20^{\mathrm{a}}$ & 10,83 & 450,70 \\
\hline $\mathrm{P} 2$ & 4,20 & 1,80 & 16,35 & $7,18^{\mathrm{b}}$ & $74,67^{\mathrm{b}}$ & 9,03 & 454,62 \\
\hline P3 & 5,07 & 1,78 & 16,32 & $7,96^{\mathrm{a}}$ & $73,95^{\mathrm{b}}$ & 8,63 & 450,43 \\
\hline \multicolumn{8}{|c|}{ Pengaruh jenis substitusi (J) } \\
\hline $\mathrm{J} 1$ & $5,09^{\mathrm{a}}$ & 1,81 & $15,23^{\mathrm{b}}$ & $6,69^{\mathrm{b}}$ & $76,26^{\mathrm{a}}$ & $11,14^{\mathrm{a}}$ & $445,04^{b}$ \\
\hline $\mathrm{J} 2$ & $4,16^{\mathrm{b}}$ & 1,78 & $17,15^{\mathrm{a}}$ & $7,45^{\mathrm{a}}$ & $73,62^{b}$ & $7,85^{\mathrm{b}}$ & $458,79^{\mathrm{a}}$ \\
\hline \multicolumn{8}{|c|}{ Pengaruh interaksi (PxJ) } \\
\hline $\mathrm{P} 1 \mathrm{~J} 1$ & $5,93^{\mathrm{a}}$ & 1,89 & $13,55^{\mathrm{c}}$ & 5,83 & 78,71 & 14,05 & $432,95^{\mathrm{d}}$ \\
\hline $\mathrm{P} 1 \mathrm{~J} 2$ & $3,49^{\mathrm{c}}$ & 1,73 & $17,92^{\mathrm{a}}$ & 6,34 & 74,02 & 8,75 & $465,84^{\mathrm{a}}$ \\
\hline P2J1 & $4,62^{\mathrm{abc}}$ & 1,78 & $15,47^{\mathrm{b}}$ & 6,92 & 75,84 & 10,90 & $448,50^{c}$ \\
\hline $\mathrm{P} 2 \mathrm{~J} 2$ & $3,79^{\mathrm{bc}}$ & 1,83 & $17,23^{\mathrm{a}}$ & 7,45 & 73,49 & 7,16 & $460,73^{\mathrm{ab}}$ \\
\hline P3J1 & $4,94^{\mathrm{ab}}$ & 1,77 & $16,33^{\mathrm{a}}$ & 7,34 & 74,57 & 9,61 & $451,06^{\text {bc }}$ \\
\hline P3J2 & $5,19^{\mathrm{a}}$ & 1,78 & $16,31^{\mathrm{a}}$ & 8,58 & 73,34 & 7,65 & $449,80^{c}$ \\
\hline
\end{tabular}

Angka yang diikuti huruf yang sama tidak berbeda nyata pada DMRT 5\%.

\section{Kadar abu}

Hasil penelitian menunjukkan rata-rata kadar abu biskuit mocaf-garut dengan substitusi hati adalah berkisar $1,73-1,89 \%$ bk. Hal ini sesuai dengan penelitian Oluwole et al. (2005), biskuit ubi kayu yang disubstitusi kacang bambara $20 \%$ memiliki kadar abu sebesar $1,34 \%$ bk.

\section{Kadar lemak}

Berdasarkan Tabel 3 biskuit yang disubstitusi dengan hati sapi cenderung memiliki kadar lemak lebih tinggi bila dibandingkan dengan biskuit yang disubstitusi hati ayam. Hal ini di- karenakan hati sapi memiliki kadar lemak jauh lebih tinggi dari pada hati ayam. Nilai kadar lemak total yang dihasilkan dari produk biskuit dalam penelitian ini berkisar $13-17 \%$ bk sudah sesuai dari standar kadar lemak total yang telah ditetapkan oleh SNI 2973:1992, yaitu minimum $9,5 \%$.

\section{Kadar protein}

Nilai kadar protein total yang dihasilkan dari produk biskuit dalam penelitian ini berkisar antara 5-8\%bk sudah sesuai dari standar kadar protein total yang telah ditetapkan oleh SNI 
2973:2011 untuk produk biskuit, yaitu minimum $5 \%$. Kandungan protein yang tinggi pada biskuit yang dihasilkan dipengaruhi oleh kandungan protein yang terdapat pada hati ayam dan hati sapi yang ditambahkan dalam pembuatan biskuit. Selain karena protein yang terdapat di dalam hati ayam dan hati sapi, tingginya kadar protein ini juga disebabkan oleh bahan campuran lain yang digunakan dalam pembuatan biskuit, yaitu penggunaan kuning telur dan susu skim. Kuning telur ayam dan susu skim diketahui sebagai bahan pangan sumber protein yang tinggi, dimana kuning telur mengandung protein sebesar 15,22 $\mathrm{g} / 100 \mathrm{~g}$ (Rahayu 2003) dan susu skim sebesar 3,5 $\mathrm{g} / 100 \mathrm{~g}$.

Kadar protein yang tinggi pada biskuit memberikan pengaruh positif, dimana tingginya kadar protein dapat membantu penyerapan zat besi yang berfungsi sebagai pembentuk sel darah merah dan untuk mempertahankan tekanan osmosis darah, sehingga dapat membantu meningkatkan sel darah merah pada balita anemia (Huma et al. 2007).

\section{Kadar zat besi}

Nilai rata-rata kadar zat besi biskuit pada perlakuan jenis bahan substitusi untuk J1 (biskuit dengan substitusi hati ayam) adalah 11,14 mg dan untuk J2 (biskuit dengan substitusi hati sapi) adalah 7,85 mg. Biskuit yang disubstitusi hati ayam memiliki kadar zat besi lebih tinggi bila dibandingkan dengan biskuit yang disubstitusi hati sapi. Hal ini dikarenakan hati ayam yang digunakan pada penelitian ini mengandung kadar zat besi lebih tinggi $(17,38 \mathrm{mg})$ bila dibandingkan dengan hati sapi $(9,95 \mathrm{mg})$. Hal ini sesuai dengan penelitian Krismaputri et al. (2013), nugget ayam yang disubstitusi hati ayam sebesar $20 \%$ dan $30 \%$ memiliki kadar zat besi berturutturut berkisar 10,40\%bk dan 9,13\%bk.

\section{Nilai energi}

Nilai energi biskuit mocaf-garut substitusi hati pada penelitian ini berkisar 440-465 kkal. Hal ini sesuai dengan penelitian Mamentu et al. (2013) yang menyatakan bahwa biskuit mocafwortel dengan perbandingan $75 \%: 25 \%$ memiliki kadar energi sebesar 496,09 kkal. Jumlah energi yang dihasilkan dari produk biskuit dalam penelitian ini sudah sesuai dari standar jumlah energi PMT (pemberian makanan tambahan) yang telah ditetapkan oleh Kemenkes (2009), yaitu minimum $140 \mathrm{kkal}$ per $35 \mathrm{~g}$ produk atau setara dengan $400 \mathrm{kkal}$ per $100 \mathrm{~g}$ produk. Tingginya energi pada biskuit dipengaruhi oleh kandungan protein, lemak dan karbohidrat yang terdapat dalam bahan yang digunakan untuk membuat biskuit cukup tinggi, sehingga dihasilkan energi yang tinggi jika dijumlahkan.

\section{Sifat organoleptik biskuit mocaf-garut substi- tusi hati}

Hasil analisis ragam (uji F) dan DMRT 5\% untuk sifat organoleptik biskuit dapat dilihat pada Tabel 4. Hasil uji statistik menunjukkan bahwa kombinasi perlakuan proporsi mocaf:garut:bahan substitusi dan jenis bahan substitusi (PxJ) berpengaruh terhadap semua variabel organoleptik.

\section{Warna}

Tabel 4 menunjukkan nilai rata-rata warna biskuit mocaf-garut substitusi hati berkisar antara 2,38-3,22 yaitu cokelat sampai cokelat tua. Nilai terendah yaitu biskuit P3J1 (proporsi mocaf-garut- bahan subsitusi $=65: 10: 25$, dan jenis bahan subsitusi hati ayam). Sedangkan nilai tertinggi yaitu biskuit P1J1 (proporsi mocaf-garut- bahan subsitusi $=75: 10: 15$, dan jenis bahan subsitusi hati ayam). Warna cokelat semakin gelap akan menurunkan kesukaan panelis terhadap biskuit. Menurut Habeych et al. (2016), produk yang difortifikasi dengan zat besi akan memiliki warna kusam sebagai akibat dari perubahan kompleks antara zat besi dan polifenol.

\section{Tekstur}

Tektur biskuit mocaf-garut yang substitusi hati dalam hal ini yang dinilai adalah keremahannya. Hasil uji statistik menunjukkan nilai rata-rata tekstur biskuit terendah dan tertinggi berturut-turut yaitu 2,22 (agak remah) dan 3 (remah). Nilai rata-rata tekstur biskuit tertinggi dimiliki P1J2 (proporsi mocaf-garut-bahan substitusi $=75: 10: 15$, dan jenis bahan subsitusi hati sapi). Biskuit dengan proporsi bahan substitusi terendah (baik itu disubsitusi hati ayam maupun hati sapi) memiliki tekstur atau keremahan yang tinggi. Hal ini disebabkan semakin rendah bahan substitusi maka akan semakin tinggi proporsi mocaf yang digunakan. Mocaf mengandung kadar pati tinggi yaitu sekitar 85-87 \% (Subagjo et al. 2008). Pada pembuatan biskuit pati akan mengalami proses gelatinisasi dan berpengaruh terhadap tekstur biskuit.

\section{Aroma}

Aroma bahan substitusi (hati ayam maupun hati sapi) merupakan faktor yang mempengaruhi aroma amis dalam produk biskuit yang dihasilkan. Hasil uji statistik menunjukkan nilai 
Tabel 4. Hasil analisis ragam (uji F) dan DMRT 5\% sifat organoleptik biskuit mocaf garut substitusi Hati

\begin{tabular}{|c|c|c|c|c|c|}
\hline Data & Warna & Tekstur & Aroma & Flavor & Kesukaan \\
\hline Chi Sq Hi & $61,44^{* *}$ & $34,74^{* *}$ & $43,64^{* *}$ & $24,76^{* *}$ & $32,25^{* *}$ \\
\hline Pembanding & 66,1572 & 66,1572 & 66,1572 & 66,1572 & 66,1572 \\
\hline \multicolumn{6}{|c|}{ Jumlah ranking perlakuan } \\
\hline P1J1 & $149,50^{\mathrm{a}}$ & $125,00^{\mathrm{ab}}$ & $139,00^{\mathrm{a}}$ & $103,50^{\mathrm{ab}}$ & $120,00^{\mathrm{ab}}$ \\
\hline $\mathrm{P} 1 \mathrm{~J} 2$ & $134,50^{\mathrm{ab}}$ & $148,00^{\mathrm{a}}$ & $91,00^{\mathrm{abc}}$ & $89,00^{\mathrm{ab}}$ & $81,00^{\mathrm{ab}}$ \\
\hline $\mathrm{P} 2 \mathrm{~J} 1$ & $123,50^{\mathrm{abc}}$ & $89,00^{\mathrm{ab}}$ & $125,50^{\mathrm{ab}}$ & $130,50^{\mathrm{a}}$ & $128,50^{\mathrm{a}}$ \\
\hline $\mathrm{P} 2 \mathrm{~J} 2$ & 106,50 abcd & $97,50^{\mathrm{ab}}$ & $75,00^{\mathrm{abc}}$ & $82,50^{\mathrm{ab}}$ & $87,50^{\mathrm{ab}}$ \\
\hline P3J1 & $55,50^{\mathrm{d}}$ & $59,00^{\mathrm{b}}$ & $119,50^{\mathrm{abc}}$ & $104,00^{\mathrm{ab}}$ & $99,00^{\mathrm{ab}}$ \\
\hline P3J2 & $58,00^{\text {cd }}$ & $106,00^{\mathrm{ab}}$ & $65,00^{\mathrm{bc}}$ & $90,00^{\mathrm{ab}}$ & $67,00^{\mathrm{ab}}$ \\
\hline \multicolumn{6}{|c|}{ Rata-rata perlakuan } \\
\hline P1J1 & $3,22^{\mathrm{a}}$ & $2,78^{\mathrm{ab}}$ & $3,22^{\mathrm{a}}$ & $2,18^{\mathrm{ab}}$ & $2,31^{\mathrm{ab}}$ \\
\hline $\mathrm{P} 1 \mathrm{~J} 2$ & $3,11^{\mathrm{ab}}$ & $3,00^{\mathrm{a}}$ & $2,80^{\mathrm{abc}}$ & $2,09^{\mathrm{ab}}$ & $2,04^{\mathrm{ab}}$ \\
\hline P2J1 & $3,02^{\mathrm{abc}}$ & $2,47^{\mathrm{ab}}$ & $3,11^{\mathrm{ab}}$ & $2,33^{\mathrm{a}}$ & $2,36^{\mathrm{a}}$ \\
\hline $\mathrm{P} 2 \mathrm{~J} 2$ & $2,85^{\mathrm{abcd}}$ & $2,53^{\mathrm{ab}}$ & $2,65^{\mathrm{abc}}$ & $2,05^{\mathrm{ab}}$ & $2,02^{\mathrm{ab}}$ \\
\hline P3J1 & $2,38^{\mathrm{d}}$ & $2,22^{\mathrm{b}}$ & $3,09^{\mathrm{abc}}$ & $2,16^{\mathrm{ab}}$ & $2,11^{\mathrm{ab}}$ \\
\hline $\mathrm{P} 3 \mathrm{~J} 2$ & $2,45^{\mathrm{cd}}$ & $2,58^{\mathrm{ab}}$ & $2,53^{\mathrm{bc}}$ & $2,09^{\mathrm{ab}}$ & $1,91^{\mathrm{ab}}$ \\
\hline
\end{tabular}

Angka yang diikuti huruf yang sama tidak berbeda nyata pada DMRT 5\%. Keterangan Skoring: Warna: 1)cokelat kemerahan, 2)cokelat, 3)cokelat tua, 4)cokelat gelap; Aroma: 1)sangat manis, 2)amis, 3)agak manis, 4)tidak manis; Tekstur: 1)tidak remah, 2)agak remah, 3)remah, 4)sangat remah; Flavor: 1)tidak enak, 2)agak enak, 3)enak, 4)sangat enak; Kesukaan: 1)tidak suka, 2) agak suka, 3)suka, 4)sangat suka.

rata-rata aroma biskuit terendah dan tertinggi berturut-turut yaitu 2,53 (amis) dan 3 (agak amis). Nilai rata-rata aroma biskuit tertinggi dimiliki oleh P1J1 (proporsi mocaf-garut-bahan subsitusi $=75: 10: 15$, dan jenis bahan subsitusi adalah hati ayam). Sedangkan nilai rata-rata aroma biskuit terendah dimiliki oleh P3J2 (proporsi mocaf-garut-bahan subsitusi $=65: 10: 25$, dan jenis bahan subsitusi hati sapi). Proporsi bahan substitusi yang semakin tinggi akan menimbulkan bau lebih amis sehingga akan menurunkan kesukaan panelis terhadap aroma.

\section{Flavor}

Hasil uji statistik menunjukkan nilai ratarata flavor biskuit berkisar 2,05-2,33 (agak enak). Nilai rata-rata flavor biskuit tidak berbeda jauh atau dapat dikatakan hampir sama dari setiap kombinasi perlakuan yang ada, namun nilai rata-rata yang dihasilkan cukup rendah sehingga biskuit dikategorikan agak enak. Hal ini dapat disebabkan oleh flavor amis yang berasal dari hati ayam dan hati sapi. Penelitian ini sesuai dengan penelitian Kiskini et al. (2007), yang menyatakan bahwa semakin besar persentase protein hewani dalam biskuit maka flavor yang dimiliki biskuit tersebut menjadi tidak enak.

\section{Nilai Kesukaan}

Tingkat kesukaan penelis berhubungan erat dengan tingkat penerimaan konsumen terhadap suatu produk. Hasil uji statistik menunjukkan nilai rata-rata kesukaan biskuit terendah dan tertinggi berturut-turut yaitu 1,91 (agak suka) dan 2,36 (agak suka). Secara umum, nilai kesukaan terhadap biskuit memiliki nilai rata-rata cukup rendah sehingga biskuit dikategorikan agak disukai. Dimana kesukaan biskuit ini sangat dipengaruhi oleh adanya substitusi hati ayam maupun hati sapi yang akan memengaruhi aroma amis produk biskuit yang dihasilkan sehingga semakin tinggi proporsi bahan substitusi akan menurunkan kesukaan panelis terhadap biskuit.

Berdasarkan Howard et al. (2012) jumlah panelis tidak terlatih (untrained) minimal 75 orang, panelis terlatih (trained) minimal sebanyak 10 orang dan panelis ahli (expert) minimal sebanyak 6 orang. Karena pada penelitian ini jumlah panelis semi terlatih sebanyak 15 orang, maka hasil uji organoleptik hanya dapat memberikan gambaran sementara terhadap tingkat penerimaan sifat organoleptik biskuit mocaf. Oleh karena itu, perlu dilakukan penelitian lanjutan sehingga didapatkan data yang lebih akurat. 


\section{Kandungan gizi biskuit mocaf-garut terbaik}

Kombinasi terbaik yang diinginkan yaitu terutama kadar zat besi tinggi dengan sifat organoleptik yang disukai. Biskuit terbaik adalah P1J1 yaitu proporsi mocaf:garut:bahan substitusi 75:10:15 dan jenis bahan subsitusi adalah hati ayam. Biskuit P1J1 memiliki kandungan energi $432,95 \mathrm{kkal} / 100 \mathrm{~g}$ dengan nilai rata-rata kadar air $5,93 \%$ bb, kadar abu $1,89 \%$ bk, kadar protein total $5,83 \%$ bk, kadar lemak total $13,55 \%$ bk, kadar karbohidrat 78,71\%bk dan kadar zat besi 14,05 $\mathrm{mg} / 100 \mathrm{~g}$.

Pembuatan biskuit yang kaya akan zat besi juga dilakukan peneliti di beberapa negara, diantaranya peneliti di Brazil. Penelitian Rebellato et al. (2015) membuat biskuit yang difortifikasi zat besi yaitu biskuit asin, krim kraker, sereal jagung, dan biskuit mentega mengandung zat besi sebesar 5,3-7,8; 5,0-8,6; 2,5-6,8; dan 3,7-5,7 mg/100g. Penelitian lain dilakukan oleh Sazawal et al. (2010), produk yang difortifikasi untuk intervensi anemia pada anak adalah susu. Susu pada penelitian ini difortifikasi berbagai mikronutrien diantaranya zat besi sebesar 9,6 mg dalam 3 takaran saji sehari. Bila dibandingkan dengan biskuit mocaf-garut perlakuan terbaik, maka jumlah zat besi biskuit mocaf-garut memiliki kandungan zat besi lebih besar yaitu 14,05 mg/100g.

Perbandingan komposisi zat gizi biskuit mocaf-garut dibandingkan dengan standar minimal nilai gizi biskuit PMT berturut-turut sebagai berikut energi $433 \mathrm{kkal}: 400 \mathrm{kkal}$, protein 5,83 g : 5,3 g, lemak 13,55 g : $12 \mathrm{~g}$, karbohidrat 78,71 g : - , zat besi 14,05 mg : 9,1 mg. Biskuit mocaf-garut memiliki nilai energi, protein, lemak, dan zat besi yang lebih tinggi dari standar minimal nilai gizi Biskuit PMT. Perbedaan signifikan terlihat pada kan-dungan zat besi dalam biskuit mocafgarut. Biskuit mocaf-garut memiliki kandungan zat besi $4,95 \mathrm{mg}(54,4 \%)$ lebih tinggi dari standar minimal kandungan zat besi dalam biskuit PMT. Hal ini merupakan salah satu keunggulan biskuit mocaf-garut karena zat besi merupakan zat gizi yang penting bagi balita untuk memelihara kadar hemoglobin dalam darah.

Persen pemenuhan biskuit dengan perlakuan terbaik terhadap kebutuhan balita anemia dapat dilihat pada Tabel 5 dengan mengonsumsi satu takaran saji biskuit $(22,8 \mathrm{~g})$ maka balita anemia dapat memenuhi asupan zat besi sebesar $3,2 \mathrm{mg}$ atau setara dengan 35,5-40\% kebutuhan akan zat besi harian. Jumlah keping biskuit yang dikonsumsi dalam 1 takaran saji sejumlah enam keping biskuit.

Apabila balita mengonsumsi biskuit sebanyak tiga kali makan selingan harian, maka kebutuhan zat besi sudah dapat dicapai atau melebihi $100 \%$ kebutuhan zat besi sehari balita anemia (106,5-120\%). Dengan tercapai-nya kebutuhan zat besi harian balita anemia, maka peneliti merekomendasikan produk biskuit mocaf-garut sebagai produk PMT bagi balita anemia. Penelitian Semba et al. (2010) menyatakan bahwa pemberian susu yang difortifikasi zat besi membuat ba-lita yang mengonsumsinya memiliki risiko anemia lebih rendah daripada anak-anak yang tidak mengonsumsinya $\quad(\mathrm{OR}=0,76 ; 95 \% \mathrm{CI}: 0,72-0,8) \quad(p<0,0001)$ di pedesaan dan $(\mathrm{OR}=0,79 ; 95 \% \mathrm{CI}: 0,74-0,86)$ $(p<0,0001)$. Hal ini menunjukkan hasil bahwa intervensi gizi dengan pemberian makanan yang diperkaya dengan zat besi akan memberikan dampak positif bagi pengu-rangan kejadian anemia.

Keunggulan lain yang dimiliki biskuit mocaf-garut selain dapat memenuhi kebutuhan zat gizi balita yaitu bahan-bahan yang digunakan adalah bahan pangan lokal yaitu ubi kayu, garut, hati ayam dan bayam merah. Bahan lokal tersebut setelah diolah menjadi biskuit cenderung lebih disukai balita dibandingkan dengan konsumsi bahan tersebut secara langsung dengan teknik pemasakan biasa seperti direbus. Selain itu peningkatan penggunaan bahan lokal mendukung ketahanan pangan bangsa Indonesia. Biskuit Mocaf-Garut ini telah memenuhi standar minimal kandungan gizi biskuit PMT dan memiliki keunggulan dalam kandungan zat besi yaitu 54,4\% kandungan zat besi lebih besar dari Biskuit PMT.

Dengan konsumsi makanan harian sesuai dengan pedoman gizi seimbang serta rekomendasi PMT biskuit mocaf-garut substitusi hati, diharapkan balita anemia dapat memenuhi kebu-

Tabel 5. Persen (\%) Pemenuhan Biskuit Hasil Perlakuan Terbaik terhadap Kebutuhan Balita Anemia (Permenkes 2013).

\begin{tabular}{lccc}
\hline \multicolumn{1}{c}{ Zat Gizi } & $\begin{array}{c}\text { Kebutuhan Balita } \\
(\mathrm{AKG})\end{array}$ & $\begin{array}{c}\text { Kandungan gizi persajian biskuit } \\
\text { terbaik }(22,8 \mathrm{~g})\end{array}$ & \%Pemenuhan \\
\hline Energi (kkal) & $1.125-1.600$ & 98,71 & $6,16-8,77$ \\
Protein $(\mathrm{g})$ & $26-35$ & 1,32 & $3,77-5,07$ \\
Zat besi $(\mathrm{mg})$ & $8-9$ & 3,2 & $35,5-40,00$ \\
\hline
\end{tabular}


tuhan harian akan zat gizi makro dan mikro sehingga anemia pada balita dapat teratasi.

\section{KESIMPULAN}

Kombinasi biskuit terbaik dari uji indeks efektivitas didapatkan dari proporsi mocaf : garut : bahan substitusi 75:10:15 dan jenis bahan subsitusi (hati ayam) memiliki kadar protein $5,83 \%$ bk dan kadar lemak total 13,55\%bk. Biskuit hasil penelitian sudah memenuhi standar mutu biskuit (SNI 2973:2011). Biskuit mengandung kadar zat besi cukup tinggi yaitu14,05 mg/100 g. satu takaran saji biskuit sebesar 22,8 g dapat memenuhi asupan zat besi sebesar 3,2 mg atau setara dengan 35,5-40\% kebutuhan balita akan zat besi harian.

Dibutuhkan penelitian lebih lanjut tentang uji penerimaan konsumen sesuai dengan jumlah panelis yang dituliskan oleh Howard et al.(2012). Selain itu dibutuhkan juga penelitian mengenai penambahan flavoran alami seperti cengkeh atau kayu manis untuk mengurangi bau amis biskuit mocaf-garut.

\section{UCAPAN TERIMA KASIH}

Peneliti penyampaikan penghargaan yang tinggi dan terima kasih kepada Kementerian Pendidikan Tinggi dan Kebudayaan yang telah membiayai penelitian riset institusional ini melalui prog DIPA BLU Unsoed Tahun 2016 dengan nomer surat kontrak : Ketua LPPM No: Kept. 2154/ UN23.14/PN.01.00/2016

\section{DAFTAR PUSTAKA}

Agustia FC, Subardjo YP, Sitasari S. 2016. Formulasi dan karakterisasi mi bebas gluten tinggi protein berbahan pati sagu yang disubstitusi tepung kacang-kacangan. J Gizi Pangan 11(3):183-190.

Aini N, Wirawani N. 2013. Kontribusi MP-Asi biskuit substitusi tepung garut, kedelai, dan ubi jalar kuning terhadap kecukupan protein, vitamin A, kalsium, dan Zink pada bayi. Journal of Nutrition College 2(4): 458-466.

Apriyantono A, Fardiaz D, Sedarnawati.1989. Analisis Pangan. Bogor: IPB Press

Ashaye OA, Olanipekun OT, Ojo SO. 2015. Chemical and nutritional evaluation of biscuit processed from cassava and pigeon pea flour. J Food Process Technol 6(12).

Davis TE, Fischer EF, Rohloff PJ, Heimburger DC, 2014. Chronic malnutrition, breastfeeding, and Ready to Use Supplementary
Food in Guatemalan Maya Town. Spring 73(1):72-81.

Escott-Stump S. 2005. Nutrition and diagnosisrelated care $7^{\text {th }}$ edition. Baltimore: Wolters Kluwer, Lippicott Williams dan Wilkins.

Faridah DN, Dedi F, Nuri A, Titi CS. 2014. Karakteristik sifat fisikokimia pati garut (Maranta arundinaceae). Jurnal Agritech 34(1):14-21.

Habeych E, Kogelenberg V, Sagalowicz L, Michel M, Gallafu N. 2016. Strategies to limit colour changeswhen fortifying food productswith iron. Food Res Int 88:122128.

Howard R, Moskowitz, Jacqueline H, Beckley, Anna VA Resurreccion. 2012. Sensory and Consumer Research in Food Product Design and Developmen, Second Edition. Blackwell Publishing Ltd. And The Institute of Food Technologists. ISBN 9781119945970. DOI: 10.1002/9781119945970.

Huma N, Rehman SU, Anjum FM, Murtaza MA. 2007. Food fortification strategy: preventing iron deficiency anemia : A review. Crit Rev Food Sci Nutr 47(3):259-265.

Kiskini S, Argiri K, Kalogeropoulos M, Komaitis M, Kostaropoulos A, Mandala I, Kapsokefalou M. 2007. Sensory characteristics and iron dialyzability of glutenfree bread fortified with iron. Food Chem 102(1):309316.

[Kemenkes RI] Kementerian Kesehatan Republik Indonesia. 2009. Spesifikasi Teknis Makanan Tambahan Anak Balita 2-5 tahun, Anak Usia Sekolah Dasar dan Ibu Hamil. Jakarta: Bina Gizi dan Kesehatan Ibu dan Anak.

Krismaputri ME, Hintono A, Pramono YB. 2013. Kadar vitamin A, zat besi (Fe) dan tingkat kesukaan nugget ayam yang disubstitusi dengan hati ayam broiler. Animal Agriculture Journal 2(1):288-294.

Mamentu AK, Nurali E, Langi T,Koapaha T. 2013. Analisis Mutu Sensoris, Fisik dan Kimia Biskuit Balita Yang Dibuat Dari Campuran Tepung MOCAF (Modified Casavva Flour) dan Wortel (Daucus carota) . in Cocos 2(4).

Mervina, Kusharto CM, Marliyati SA. 2012. Formulasi biskuit dengan substitusi tepung ikan lele dumbo (Clarias gariepinus) dan isolat protein kedelai (Glycine max) sebagai makanan potensial untuk balita gizi kurang. J Teknol dan Industri Pangan 23(1):9. 
Oluwole OB, Karim OR. 2005. Production of biscuits from bambara, cassava and wheat flour blends. Journal of Raw Material Research 2(1):34-38.

Onabolu A, Oluwole OB M, Rosling, H. 2001. Ecological variation of intake of cassava food and dietary cyanide load in Nigerian communites. Public Health Nutr 4(4):871876.

[Permenkes RI] Peraturan Menteri Kesehatan Republik Indonesia. 2013. Peraturan Menteri Kesehatan Republik Indonesia Nomor 75 Tahun 2013 Tentang Angka Kecukupan Gizi yang Dianjurkan Bagi Bangsa Indonesia. Jakarta: Kemenkes RI.

Rahayu I. 2003. Karakteristik fisik, kimia, uji organoleptik telur ayam Merawang dengan pemberian pakan bersuplemen omega 3. Jurnal Teknologi dan Industri Pangan 24(3).

Rebellato AP, Pacheco BC, Prado JP, Pallone JAL. 2015. Iron in fortified biscuits: A simple method for its quantification, bioaccessibility study and physicochemical quality. Food Res Int 77:385-391.

Santosa H, Handayani NA, Nuramelia C, Sukma, NYT. 2016. Pemanfaatan hati ayam sebagai fortifikan zat besi dalam bubur bayi instan berbahan dasar ubi jalar ungu (Ipomoea Batatas L.). Inovasi Teknik Kimia 1(1):27-34

Sazawal S, Dhingra U, Dhingra $P$, Hiremath G, Sarkar A, Dutta A, Menon VP, Black RE. 2010. Micronutrient fortified milk improves iron status, anemia and growth among children 1-4 years: A double masked, randomized, controlled trial. Plos One 5(8):12167.
Semba RD, Moench-Pfanner R, Sun K, de Pee S, Akhter N, Rah JH, Campbell AA, Badham J, Bloem MW, Kraemer K. 2010. Iron-fortified milk and noodle consumption is associated with lower risk of anemia among children aged 6-59 mo in Indonesia. Am J Clin Nutr 92(1):170-176.

Sianturi DP, Marliyati SA. 2014. Formulasi flakes tepung komposit pati garut dan tepung singkong dengan penambahan pegagan sebagai pangan fungsional sarapan anak sekolah dasar. J Gizi Pangan 9(1): 15-22.

Simbolon DOS, Masfria, Sudarmi. 2012. Pemeriksaan kadar $\mathrm{Fe}$ dalam hati ayam ras dan ayam buras decara dpektrofotometri serapan atom. J Nat Prod Pharma Chemi 1(1):8-13.

[SNI]. Standar Nasional Indonesia. 2011. Syarat Mutu Biskuit SNI 2973:2011. Jakarta: Dewan Standar Indonesia, Badan Standarisasi Nasional.

Soekarto, ST. 1985. Penilaian Organoleptik untuk Industri Pangan dan Hasil Pertanian. Jakarta: Bharata Karya Aksara.

Subagjo A, Witono Y, Fahmi F. 2008. Prosedur Operasi Standar (POS) Produksi Mocaf Berbasis Kluster. Trenggalek: Kementerian Negara Riset dan Teknologi:1-5.

[USDA] United State Department of Agriculture. 2014. Basic Report: 05027. National Nutrient Database for Standard Reference Releases.

Widaningrum,Widowati S, Soekarto ST. 2005. Pengayaan tepung kedelai pada pembuatan mie basah dengan bahan baku tepung terigu yang disubtitusi tepung garut. Jurnal Pascapanen 2(1):41-48. 